\title{
Russia's Changing Attitude toward the OSCE: Contradictions and Continuity
}

\author{
Viatcheslav Morozov*
}

\begin{abstract}
Russia's attitude toward the OSCE has undergone a dramatic transformation in recent years - instead of supporting the Organization as the cornerstone of European security, Russia has come to criticize it for being misbalanced and/or irrelevant. This apparent change can be interpreted as a constant pattern in Russian political discourse, which defines Russia as the continuer state of the Soviet Union, and thus as a great power. Previously, this set the OSCE up against NATO; presently, the OSCE has been marginalized because Russia has an ostensibly better way to influence global affairs by cooperating with the US in the anti-terrorist coalition. This latter position is inherently contradictory and unsustainable, but the adoption of a more rational approach would require an exceptionally favourable combination of several key factors.
\end{abstract}

Keywords: Russia, OSCE, sovereignty, identity, security

$\mathrm{R}$ ussia's attitude toward the Organization for Security and Co-operation in Europe (OSCE) has always been contradictory. Moscow has often preferred to promote the OSCE as »the cornerstone of European security, « while playing down some of the aspects of the Organization's activities. The recent years, however, have witnessed a steady decline in OSCE's fortunes with Russian foreign policy elites. This article examines the nature of Russia's contradictory attitude toward the Organization, and attempts to explain the reasons why present-day Russian politicians as well as analysts prefer to emphasize those features of the OSCE, which they see as incompatible with the political and security reality of contemporary Europe.

\section{Soviet Legacy and the Concept of the Continuer State}

Structurally, Russian foreign policy discourse puts the OSCE very much in the same position as Soviet discourse did during the ten years between the Helsinki Final Act and the beginning of Mikhail Gorbachev's Perestroika. It is widely known that the Soviet Union always emphasized the importance of the first basket negotiated at the Conference on Security and Co-operation in Europe, which resulted in the two principles enshrined in the Final Act of 1975 - the inviolability of Europe's borders established at the end of World War II and the principle of noninterference into the internal affairs of sovereign states. Moscow also approved of the second basket, which expanded the Soviet access to Western technology and opened the Soviet market to the Western European industry. The third basket, aiming at intensifying cultural and humanitarian cooperation, on the basis of respect for human rights, was a concession on the part of the Soviet leaders, who feared that it might undermine the supremacy of the Soviet ideology with its stress on social and economic rights, as distinct from the »bourgeois « concept of civil and political rights. In a sense, one may argue that history has proven they were right: the fact that the USSR signed the Final Act has provided human rights activists within the Soviet Union with a powerful political resource. The Moscow Helsinki
Group was founded in 1976 and has become (and remains up until today) one of the most authoritative non-governmental organizations active in the field of human rights protection. In general, the increasing prominence of individual rights and freedoms has played a vital role in eroding the legitimacy of the declining Soviet system. ${ }^{1}$

After a brief period of experimenting with universal liberal values as the basis for foreign policy under Gorbachev and the first Russian president Boris Yeltsin - which resulted, inter alia, in the signing of the Paris Charter for a New Europe and the Conventional Forces in Europe (CFE) Treaty in 1990 - Moscow's political establishment by the mid-1990s had returned more or less to the same old pattern. The emphasis was put again on sovereignty and the inviolability of borders, while the importance of individual rights and freedoms was generally played down, and accepted only in a very limited number of cases. To a large extent, this had to do with the fact that the Russian Federation was increasingly defined as the heir of the Soviet Union, not only in legal, but also in geopolitical and historiosophical terms, while all alternative identifications were being marginalized in political discourse. ${ }^{2}$ However, the working of this mechanism was not as straightforward as sometimes presented by the proponents of full historical continuity between today's Russia and the Soviet Union. ${ }^{3}$ Both Russian society and the world have been undergoing a process of steady changes during the last two decades, and this continuity should not obscure the phenomena that were pivotal in changing Moscow's attitude toward the OSCE in the late 1990s- early 2000s.

\footnotetext{
* Dr. Viatcheslav Morozov, Associate Professor of the School of International Relations, St. Petersburg State University, Russia.

1 See e.g. Maresca, John J., To Helsinki: The Conference on Security and Cooperation in Europe, 1973-1975, Durham: Duke University Press, 1985; Alekseeva, Liudmila, Istoriya inakomysliya v SSSR: noveishii period, Moskva: Zatsepa, 2001.

2 See Matz, Johan, Constructing a Post-Soviet International Political Reality. Russian Foreign Policy Towards Newly Independent States 1990-1995. Uppsala: University of Uppsala, 2001; Morozov, Viatcheslav, »Identity Crisis and Democratic Market Reforms in Russia, « in M. Lane Bruner and Viatcheslav Morozov (eds), Market Democracy in Post-Communist Russia. Leeds: Wisdom House, 2005, pp. 252-281.

3 See e.g. Narochnitskaya, Natalya, Rossiya i russkie v mirovoi istorii, Moskva: Mezdunarodnye otnoshenia, 2003.
} 
After the collapse of the Soviet Union, the new Russia found itself in a situation of geopolitical retreat. The Russians tried to catch up with the »civilized world « of the Western powers, but this new identity did not receive sufficient external affirmation. When the Soviet Union and later the Russian Federation tried to behave as if it were part of the West, putting the interests of the »international community « above its own, historicallyrooted concerns were rather perceived in the Western capitals as concessions on part of a dwindling superpower than as a sign that Russia was to be welcomed as one of »our own«. Support for the US and its allies during the first Gulf War, the acquiescence to the German unification, which involved Germany's membership in NATO, the complete withdrawal of Russian troops, the more or less silent approval of the Western policy in the Balkans at the initial stages of the conflict there - all this, and much more, was accepted by the West, but reaped no rewards. Russia was only reluctantly accepted into such institutions as the G7 and the Council of Europe; NATO launched its enlargement process, which, from the Russian perspective, had no clear rationale; and, after initial euphoria, there came a painful mutual disillusionment as regards the actual motives and effectiveness of Western financial aid. ${ }^{4}$ Moreover, Russia soon came under harsh criticism for its failure to meet the high democratic standards, which, after the end of the Cold War, were increasingly instituted as universal human values.

The result was that the Russians - almost straight across the board - became terribly disappointed with the values they perceived as being offered to them, or even imposed upon them, by the West, such as market economy, democracy, human rights, etc. These values were reinterpreted as an ideological smokescreen intended to conceal the »real« political aims of the West. The liberal institutionalist worldview was again replaced by a Soviet-style realism, which was deeply immersed in geopolitical metaphysics and, in particular, saw the West as the key geopolitical rival of Russia, whose final aims were to subvert and destroy the uniqueness of Russian civilization. ${ }^{5}$ State sovereignty, which was seen by the Soviet leaders as the main guarantee for the preservation of the »historic achievements of real socialism, « again became the primary factor in safeguarding against the intrusion of Western values onto Russian soil. This was one of the key reasons why, in the late 1990s, Russia put so much emphasis on strengthening those institutions, such as the United Nations and the OSCE, which were based on, and upholding, the principle of state sovereignty.

After the collapse of the Soviet Union, Russia faced a number of territorial claims from its neighbours, including those in Europe. The most vocal were of course Estonia and Latvia, who initially sought to reinstate, respectively, the Tartu and Riga peace treaties of 1920 in their entirety, including their territorial provisions as the cornerstones of their independent

4 See e.g. Wedel, Janinie R., Collision and Collusion. The Strange Case of Western Aid to Eastern Europe, N.Y.: Palgrave, 2001.

5 For a more detailed discussion, see Morozov, Viatcheslav, »Resisting Entropy, Discarding Human Rights. Romantic Realism and Securitization of Identity in Russia, "Cooperation and Conflict, 37 (4), 2002, pp. 409-430. statehood. ${ }^{6}$ Germany has never officially put forward any claims to Kaliningrad/Königsberg, and the Finnish government has been very cautious in treating the problem of Eastern Karelia, but nevertheless Russia was, and still is, anxious about possible territorial claims from those quarters. ${ }^{7}$ With the establishment of the Yalta/Potsdam system, the Soviet Union got on the winning side. ${ }^{8}$ It should therefore come as no surprise that the Russian Federation is trying to preserve whatever is left of the post-war European order. This was an additional reason why the foundational principles of the OSCE and, first of all, the inviolability of borders, were so central to Russian foreign policy throughout the 1990s.

\section{Europe, Sovereignty and the West}

Those principles constitutive of the modern territorial state are usually interpreted as being challenged by the neo-liberal globalization, which, in countries such as Russia, are usually seen as an external factor, originating in the West and influencing the domestic situation. However, in contrast to the Soviet propaganda, where the West was often seen as a single, unified hostile force, post-Soviet Russia has developed a much more differentiated picture of the West, where differences between the US and (Western) Europe play an important role. The latter is often still understood in Russia as Europe of the nineteenth century, where territory is the main stake in international politics and state sovereignty is firmly established as the key organizing principle. The US, on the contrary, is often presented as a non-European force trying to destroy the European order by undermining the territorial foundations of politics and to reinforce its unilateral dominance in world affairs. The NATOled intervention in Kosovo in 1999 and, later, the war in Iraq, were most commonly quoted as evidence of US hegemonism and total disrespect of international norms. NATO, for that matter, is almost synonymous with the US, and is often presented as a projection of American influence in Europe.

Although Russia feels alienated from the West and even perceives it as a geopolitical rival, it still has not developed an alternative policy which would define the Russian state (or the Russian nation) as being completely independent from the »civilized world.« Europe is absolutely essential for Russia's identity; it is impossible to define Russia without relating

6 For an exhaustive but concise summary of the Russian position on this issue, see Chernichenko, Stanislav V., »Sobytiya v Pribaltike 1940 goda kak predlog dlia diskriminatsii russkoyazychnogo naseleniya, « Mezhdunarodnaya zhizn', 3, 1998, pp. 62-67.

7 For instance, see a summary of the reaction to the February 2005 statement by the Presidential Plenipotentiary in the North-Western Federal District Ilya Klebanov that Kaliningrad was to be declared an »overseas territory «: Momot, Maksim, »Putin otsenit Klebanova, "Politicheskii zhurnal, 6, 21 February 2005 (available online at www.politjournal.ru). In January 2005, an opinion poll in Finland about the Karelian issue caused an angry reaction of the Russian Ministry of Foreign Affairs: Stenogramma vystuplenia $i$ otvetov Ministra inostrannykh del Rossiiskoi Federatsii S. B. Lavrova na voprosy rossiiskikh SMI na press-konferentsii po itogam konferentsii NPO, g. Petrozavodsk, 18 yanvaria 2005 goda (available online at www.mid.ru).

8 The discussion around the $60^{\text {th }}$ anniversary of the victory over Nazi Germany abounded with positive references to Yalta and Potsdam. For example, see the reaction of the Russia Foreign Ministry to George W. Bush's statement in Riga: Kommentarii Departamenta informatsii $i$ pechati MID Rossii v otnoshenii »nepriznania « vstuplenia pribaltiiskikh respublik $v$ sostav SSSR, 7 May 2005 (available online at www.mid.ru). It is also interesting that, in this statement, the Yalta, Potsdam and Helsinki accords are quoted as events of the same rank as regards their present-day significance. 
it to Europe. Rivalry, alienation, and the desire to identify with its Western neighbours go hand in hand with Russia's identity construction process. This is the key reason why so much emphasis, especially in the late 1990s, was placed on those few institutions which provided an unproblematic link between Russia and Europe, Russia and the »civilized world.« The United Nations and the OSCE are perhaps the only two international bodies where Russia (being the legal successor of the USSR) is a founding member and where, therefore, its membership cannot be subject to doubt. While the UN is crucially important as an institution, which has endowed Russia with the status of a global great power, the OSCE was, for a certain period, perceived as playing the same role in the European context.

Another important factor behind the Organization's significance was the implicit or explicit understanding that it was constituting an alternative to NATO and thus, in a way, a counterbalance to US influence in Europe. The norms and principles of Helsinki were contrasted with the unilateralism of the US and its allies - sometimes the latter were explicitly accused of violating the provisions of the Helsinki Final Act and the Vienna Declaration of 1989. ${ }^{9}$ The signing of the European Security Charter at the Istanbul summit of 1999, after protracted negotiations, was hailed as a great success for Russian diplomacy, but as a net loss for the West: »Russia has defeated the West in the Istanbul game, « ran one of the headlines in Nezavisimaya gazeta. ${ }^{10}$

The attitude to the OSCE's human rights agenda remained ambiguous because of the harsh criticism against Russia mounted by the Organization's officials, in particular, in connection with the two Chechen campaigns. This was especially disturbing for the Russian diplomats and policy makers because it undermined the sovereign right of the Russian state to exclusive control of its internal affairs. As Deputy Foreign Minister Evgenii Gusarov stated in June 2000, »[T] here is direct evidence of the attempts to convert the OSCE into a mechanism for interference in the internal affairs of some member states, into a kind of a 'democratiser' of the European periphery, as well as into a tool for the expansion of the Western influence, including the implantation of the behavioural stereotypes and values of the Western European civilisation in the entire OSCE space. ${ }^{11}$

This reference to the West as the main culprit was made even more explicit on the eve of the Istanbul summit, when the same Nezavisimaya gazeta warned its readers that »The US wants to turn the OSCE into a tool to pressurise Russia.«"However, because it turned out that the outcome of the summit could have been interpreted as a success, Russian diplomats and commentators returned to the old tactics of playing up their standard agenda and discarding the charges against Russia as a fiction. The Director of the Department for pan-European

9 »Soedinennye Shtaty Evropy, « Nezavisimaya gazeta, 25 March 2002; Voronov, Konstantin, »Evropa i Rossiya posle balkanskoi voiny 1999 g.: dramatichnye uroki, « Mirovaya ekonomika i mezhdunarodnye otnosheniya, 4, 2000 , p. 27

10 Gornostaev, Dmitrii, »Rossiya vyigrala u Zapada stambul'skuyu partiyu, « Nezavisimaya gazeta, 20 November 1999

11 Gusarov, Evgenii P., »Helsinkskii protsess vo vneshnei politike Rossii, Diplomaticheskiy vestnik, 7, 2000, p. 93.

12 Gornostaev, Dmitrii, »SShA khotiat sdelat' OBSE instrumentom davleniya na Rossiyu, « Nezavisimaya gazeta, 13 November 1999. cooperation of the Russian Foreign Ministry, Vladimir Chizhov, writing on the outcome of the Istanbul summit, applauded »the activity of the Organisation on the issue of the respect for the rights of the Russian-speaking population in the Baltic countries. «He continued by condemning those »wishing to quite simply 'forget' the war on the Balkans, by substituting the Kosovo theme - a real source of concern for the OSCE - with criticism against Russia in connection with Chechnya. ${ }^{13}$

In the end, the benefits of Russia's active membership in the OSCE were deemed to outweigh the disadvantages, which, as evident from the above quotations, were interpreted as stemming from the »outside, « from non-European interference, and not inherent in the Organization's structure. This attitude was reflected in the Foreign Policy Doctrine of the Russian Federation, approved by the new president Vladimir Putin in June 2000. In the »Regional Priorities « section, the OSCE is first in the list of the most important partner organizations in Europe, and thus is second in significance only to the Commonwealth of Independent States. ${ }^{14}$ This fully corresponds to the fact that both this document and the National Security Doctrine argue that Russia's national security is jeopardized by »the trend to a unipolar world structure economically and militarily dominated by the US, « as well as the fact that the Western institutions, limited in terms of their membership, have started playing a central role in providing security at the expense of the UN Security Council, and that force is used with little regard for international law. ${ }^{15}$

\section{The New Disappointments and the 9/11 Effect}

The Foreign Policy Doctrine of 2000 was still valid at the time of this writing, but it is absolutely clear that Russian foreign policy priorities have changed dramatically since the document was adopted. A more critical attitude toward the OSCE is already discernible in the article by Deputy Director of the Department of Pan-European Cooperation of the Foreign Ministry Aleksandr Alekseev, published in April 2001. ${ }^{16}$ By contrast, Foreign Minister Sergei Lavrov, appointed in 2004, comes very close to discarding the Organization as irrelevant, effectively saying that Moscow sees no possibility to cooperate within its framework unless and until it is profoundly reformed. According to the Minister, the OSCE failed to fulfil the expectations of it becoming a genuinely inclusive institution after the end of the Cold War: »[P]aradoxically, this organization is erecting a wall within itself, artificially dividing its members into the NATO and EU members, and the rest. [...] As it turns out, NATO deals with security issues, the EU with economic issues, while the OSCE will only monitor the adoption of these organizations' values by countries that have remained

13 Chizhov, Vladimir A., »Stambul'skii sammit, « Mezhdunarodnaya zhizn', 12, 1999, pp. 39-40.

14 Kontseptsiya vneshnei politiki Rossiiskoi Federatsii. Utverzhdena Prezidentom Rossiiskoi Federatsii V. V. Putinym 28 iyunia 2000 g. Available online at: www.mid.ru.

15 Ibid; cf. Kontseptsiya natsional'noi bezopasnosti Rossiiskoi Federatsii. Utverzhdena Ukazom Prezidenta Rossiiskoi Federatsii N 24 ot 10 yanvaria 2000 g. Available online at: www.mid.ru.

16 Alekseev, Aleksandr N., »Rossia v evropeiskom politicheskom pole, « Mezhdunarodnaya zhizn', 4, 2001, pp. 22-29. 
outside the EU and NATO. ${ }^{17}$ This is essentially the argument about double standards applied by the West in its policy of promoting universal standards of democracy and human rights, which has become commonplace in Russian political discourse since the mid-1990s. ${ }^{18}$ As such, it is not a novelty - it has been persistently applied to the OSCE, as well as to the Council of Europe, the EU and other international bodies for the last ten years. What is new is that this argument has lead to the outright rejection of the OSCE as an institution in its present form. This dramatic shift cannot be explained by simply saying that Russian foreign policy elites have become »even more« disappointed with Western practices.

Russia has indeed experienced some very deep disappointments with the OSCE during the first years of the twenty-first century. ${ }^{19}$ At the Istanbul summit, it made what has again been interpreted as unilateral concessions (similar to those at the beginning of the 1990s) by promising to withdraw its peacekeepers from Transdniestria and to close two out of four military bases from Georgia. ${ }^{20}$ The rewards for that were marginal, if any. The modified CFE Treaty has up until now not been signed by the Baltic States. ${ }^{21}$ In 2001, the OSCE missions in Estonia and Latvia were closed down, despite the fact that a significant proportion of the Russian-speaking minorities there remain stateless and poorly integrated in their respective societies. ${ }^{22}$ Russia is deeply concerned with the developments in Kosovo and Macedonia, where it sees the position of the OSCE as biased in favour of the Albanian side. ${ }^{23}$

Last but not least, the majority of Russians was sincerely disappointed with the OSCE's performance as an institution claiming to ensure free and fair elections in the post-Soviet space. While the Russian parliamentary and presidential elections were censured as »free but not fair, « and while the Belarusian polls were condemned as violating democratic norms, the Orange Revolution in Ukraine was welcomed by everyone in the West as a genuine manifestation of the people's will. One does not have to agree with the allegations, so widespread in the Russian discussion, that the revolution was instigated and sponsored by the West in order to observe that the events did not unfold quite in accordance with the legal provisions which are supposed to apply to the electoral procedure. ${ }^{24}$ In the end, the decision to approve of the success of Viktor Yushchenko is a political decision, which has little to do with the notion of the rule of law, and therefore it is no surprise that Russia, perceiving Yushchenko's victory as its own defeat, is deeply

17 Lavrov, Sergei, »Democracy, International Governance, and the Future World Order, « Russia in Global Affairs, 3 (1), 2005, pp. 151-152.

18 Cf. Lavrov, Sergei, »Reform will enhance OSCE's relevance« Financial Times, 29 November 2004.

19 For a brief inventory of disappointments, see Yakovenko, Aleksandr V., "Est' li u OBSE budushchee?«Rossiiskaya gazeta, 13 April 2005.

20 An assessment of this step in the overall context can be found in: Lukin, Vladimir, »God posle Stambula, « Nezavisimaya gazeta, 9 November 2000. On Transdniestria, see Hill, William, "Making Istanbul a Reality: Moldova, Russia, and Withdrawal from Transdniestria, "Helsinki Monitor, 2, 2002, pp. 129-145.

21 For a summary of Moscow's official position see: Azimov, Anvar, »OSCE at the Crossroads, «International Affairs (Moscow), 51 (2), 2005, p. 61.

22 Gregory Feldman interprets this situation as marginalization of the OSCE, mainly by the EU with its enlargement project: Feldman, Gregory, "Stabilizing Estonia: The International Dimension of State Security and Ethnic Integration Policy, « Demokratizatsiya, 11 (4), 2003, pp. 555-571.

23 Shustov, Vladimir, "OSCE's Place in Europe's Architecture, "International Affairs (Moscow), 48 (1), 2002, pp. 42-44

24 See e.g. Levkin, Anatolii, »Krizis vybornosti, « Apoligia, 1(1), 2005, pp. 12-18. dissatisfied with the position of, inter alia, the OSCE. The same pattern applies to the elections in Georgia in 2003, Moldova in 2005, and to some extent also to the Kyrgyz events of the current year.

At the same time, however important the cumulative effect of these numerous disappointments are, it does not in my view amount to a satisfactory explanation for the qualitative change in Russia's attitude toward the OSCE, a development which has unfolded during the last several years. As in many other cases, the profound impact of September 11 on the global political setting must be dealt with here. Despite the fact that Russia is still extremely concerned with US unilateralism, the anti-terrorist coalition being offered by President Bush offers some substantial advantages over the institutionalist settings promoted by the Europeans, and to some extent supported by US democrats. It is clear that the current US administration, despite its pro-democracy rhetoric, is ready to turn a blind eye to the numerous faults of the Russian political system when measured by the strict standards of democracy. As long as Moscow supports Washington in its anti-terrorist endeavour, even such conflicts, as the one over the legitimacy of the war in Iraq, remain of very limited significance. And what is most important in this arrangement, and lacking in the OSCE, the Council of Europe and other similar bodies, is the recognition of Russia's status as a great power comparable with the US as the global dominant power. By cooperating with the US directly, and above all formal institutional arrangements, Russia feels as if it was regaining the global status lost with the collapse of the Soviet Union. This feeling is further supported by the economic recovery of recent years. ${ }^{25}$ As previously argued, Russian society was unable to elaborate an identity for the new Russia, which would separate it from the USSR and provide for a fresh sense of common destiny, indispensable for any community which is called a nation. In as much as today's Russia is defined through a reference to the USSR, a global partnership with the US, however shallow it may seem regarding its substance, will, in the eyes of the Russian leaders, be preferable to the complicated and burdensome cooperation with the European institutions.

\section{Europe: Russia's Unachievable Destiny}

There is, however, a profound contradiction which threatens the whole enterprise. Identifying itself as the continuer-state to the Soviet Union, Russia inevitably enters a zero-sum game which is destined to play against the West, and therefore, by definition, against the US. Indeed, the whole structure of the argument Russia has brought up against the OSCE makes no sense outside a worldview where Russia and the West figure as two separate actors in world politics competing against each other for spheres of influence. Hence, being a loyal ally of the US in the framework of the anti-terrorist coalition is for Russia a mission impossible: putting all of its geopolitical eggs into this basket, Moscow cannot go beyond purely rhetorical support for George Bush in his global design. Anytime

25 Cf.: Nikonov, Vyacheslav, »OSCE and Russia: Old Bridges, New Divisions, « Helsinki Monitor, 1, 2003, pp. 22-23. 
Western influence extends to countries that Russia considers its natural sphere of influence - and which happen to be at least as important as Russia itself in the context of war on terror - the Russians feel threatened and betrayed. The experience of the early 1990s is repeated in a radically new context: Russia's identity as part of the »civilized world « once again remains a purely internal matter and gets little to no confirmation from the outside world.

What is more, there is a good chance that Russia might become marginalized even within in the anti-terrorist coalition. With Ukraine and Georgia cherishing more and more realistic expectations of NATO membership, with Kyrgyzstan and Uzbekistan remaining - under very different conditions - close allies of the US, there is no need to fill up the vast geopolitical space called Russia with any substantial content in the framework of the coalition. With its painful Chechen problem and the long border with Kazakhstan, with its suspicious attitude toward any Western engagement in the post-Soviet space, which the West does not understand and therefore meets with irritation, Russia may become in the eyes of George Bush and his team a net consumer of security instead of a net producer. No one will punish Russia for that - it will just be ignored so long as there is some »stability« in the most formal sense of the word.
Assuming that Russian policy-makers make rational choices, these considerations would perhaps motivate them to look again at the European institutional landscape in their search for resources which can be used to overcome international isolation. The Organization for Security and Co-operation in Europe, where, unlike in the European Union, Russia is a member, and which, unlike the Council of Europe, is in principle capable of engaging in a wide range of activities, can theoretically be such an important resource. However, this conclusion rests on too many assumptions which can hardly be deemed tenable. It assumes that foreign policy is based on rational decisions of fully informed individuals, who are predominantly concerned with the interests of their nations. It further assumes that Russia can easily give up its post-Soviet identity as »irrational « and view European and global politics as a non-zero-sum game. Finally, it assumes good will on behalf of Western European politicians, who are genuinely concerned with having a democratic and prosperous Russia on board as a partner in the process of constructing a »Europe whole and free. « These are the prerequisites at this stage for Russia changing its attitude toward the OSCE and not being disappointed again in a few years time. And given the prerequisites, one may conclude that the Organization faces some more difficult years ahead.

\title{
Medienfreiheit als sicherheitspolitische Voraussetzung
}

\author{
Die OSZE im Spannungsfeld zwischen sicherheitspolitischer Stabilität und men- \\ schenrechtlicher Veränderung \\ Freimut Duve/Christian Möller*
}

\begin{abstract}
From its beginning the CSCE/OSCE was a comprehensive tool for security policy and co-operation in Europe. This includes civil liberties and human rights as an integral part. However, the so-called human dimension and security policy are no contrasts. Quite the opposite, human rights together with rule of law are basic fundaments for civil societies, peace and security, as the three independent OSCE institutions in the Human Dimension indicate. This article shows the importance of the Third Basket in the Helsinki process in general and the impact of media freedom on stable societies in particular. Freedom of expression is not at the endpoint of the development of democratic societies, but one of the prerequisites.
\end{abstract}

Keywords: CSCE/OSCE, media freedom, OSCE Representative on Freedom of the Media, human security, human and civil rights, Human Dimension, Helsinki

\section{Die »humanitäre Dimension« der KSZE}

$\mathrm{D}$ ie erste Konferenz über Sicherheit und Zusammenarbeit in Europa (KSZE) fand in einer Zeit statt, die geprägt war durch den Kalten Krieg, militärische Aufrüstung und den Dualismus der beiden Blöcke. In Wien finden parallel zur KSZE die 1973 begonnenen MBFR-Verhandlungen ${ }^{1}$

\footnotetext{
* Freimut Duve, von 1998-2003 OSZE-Beauftragter für Medienfreiheit von 1980-1998 Abgeordneter des Deutschen Bundestages, Hamburg/ Christian Möller, M.A., Project Officer im Büro des OSZE-Beauftragten für Medienfreiheit, Wien.

1 MBFR: Mutual and Balanced Force Reductions.
}

zur Truppenreduzierung in Mitteleuropa statt. Vor diesem Hintergrund sind auch die Entstehung und Aufgaben der KSZE zu sehen. Doch dabei darf nicht vergessen werden, dass sich die KSZE bereits in ihren Anfängen als umfassendes Instrument der Sicherheitspolitik und Friedenssicherung durch Zusammenarbeit verstand, und Menschen- und Bürgerrechte seit jeher zu ihren integralen Bestandteilen gehören. 